\title{
Detection of hoof lesions using digital infrared thermography in dairy cows
}

\author{
M. Alsaaod and W. Büscher ${ }^{1}$ \\ Institute for Agricultural Engineering, Livestock Technology Section, University of Bonn, Nussallee 5, D-53115 Bonn, Germany
}

\begin{abstract}
The objective was to investigate infrared thermography (IRT) as a noninvasive diagnostic tool for early detection of foot pathologies in dairy cows. This was achieved by measuring changes in coronary band temperature before and after claw trimming in response to visual detection of abnormalities of the hooves. We hypothesized that by focusing on the coronary band region, IRT is able to detect lesions of the hind limbs of dairy cows associated with lameness. In this study, 626 individual observations were collected from 24 cows before and after claw trimming. Infrared thermography was used to assess the surface temperature of the coronary band $(\mathrm{CB})$ region and skin $(\mathrm{S})$, and the temperature difference $(\Delta \mathrm{T})$ between $\mathrm{CB}$ and $\mathrm{S}$ of the hind limbs. The average, minimum, and maximum surface temperatures were recorded in both regions. Temperatures of $\mathrm{CB}$ and $\mathrm{S}$ and $\Delta \mathrm{T}$ were significantly higher in cows $\leq 200 \mathrm{~d}$ in milk than in cows $>200 \mathrm{~d}$ in milk for all healthy hooves: $31.8 \pm 2.7$ versus $29.8 \pm 3.6 ; 28.5 \pm 2.5$ versus $27.2 \pm 3.3^{\circ} \mathrm{C}$, and $3.31 \pm 1.7$ versus $2.51 \pm 1.3^{\circ} \mathrm{C}$, respectively. Temperatures of $\mathrm{CB}$ and $\mathrm{S}$ regions were positively correlated with ambient temperature. This association was best described by a linear model $\left(\mathrm{R}^{2}=\right.$ 0.92 and 0.99 , respectively). The temperatures of $\mathrm{CB}$ and $\mathrm{S}$ regions were $30.3 \pm 3.2^{\circ} \mathrm{C}$ and $27.3 \pm 2.9^{\circ} \mathrm{C} ; 32.1$ $\pm 1.7^{\circ} \mathrm{C}$ and $28.6 \pm 2.1^{\circ} \mathrm{C}$; and $33.8 \pm 1.3^{\circ} \mathrm{C}$ and $29.9 \pm$ $1.8^{\circ} \mathrm{C}$ for parlor temperatures of $12.2,15.7$, and $20.3^{\circ} \mathrm{C}$, respectively. In the pre- and post-trimming data analysis, a significant difference was found in temperature of the coronary band between cows with lesions and cows without lesions. A threshold value was established to determine the temperature difference between lesion and nonlesion hind claws on $\mathrm{CB}$ at 0.64 and $1.09^{\circ} \mathrm{C}$ before and after claw trimming (sensitivity $=85.7 \%$, specificity $=55.9 \%$; and sensitivity $=80.0 \%$, specificity $=82.9 \%$, respectively) with the aim of detecting hoof lesions. In conclusion, the results demonstrate an increase in surface temperature of the lame limb when a hoof has a lesion.
\end{abstract}

Received July 25, 2011.

Accepted September 28, 2011.

${ }^{1}$ Corresponding author: buescher@uni-bonn.de
Key words: infrared thermography, dairy cow, lameness, coronary band

\section{INTRODUCTION}

Lameness is recognized as one of the most overlooked and underestimated health problems in dairy cows (Whay et al., 2003; Rutherford et al., 2009) and is considered one of the most serious economic and welfare issues in the modern dairy industry, resulting in productive and financial losses (Green et al., 2002). Claw disorders and reduced locomotion may cause considerable suffering for the cows, because most cases of lameness are long lasting and painful (Whay et al., 1998). Therefore, efforts to prevent claw lesions become even more important for effective and successful treatment to reduce economic losses and to improve animal welfare.

The most common method to detect claw pathologies is to measure the outcome of injuries through visual observations of cow gait associated with impaired locomotion (Flower and Weary, 2006). This approach is time-consuming, labor-intensive, has a lack of clear identification standards, and depends on the skill of the observer in recognizing subtle locomotion anomalies (Winckler and Willen, 2001). Moreover, locomotion scoring may not be sufficiently sensitive to detect all claw lesions, and some types of foot lesion can be detected only at certain severities that are associated with reduced locomotion (Tadich et al., 2010).

The majority of lameness is caused by claw abnormalities. Many studies reported that diseases of the claw are associated with approximately $90 \%$ of all lameness incidents, with 76 to $84 \%$ of foot lesions occurring in the hind limbs (Murray et al., 1996). Several studies documented the topic of electronic lameness detection by automatic recording the behavior of dairy cattle, such as gait and weight distribution of individual cows in walking or standing (Pastell et al., 2006; Alsaaod and Büscher, 2009; Liu et al., 2011).

Although routine claw trimming is a good management practice to prevent claw disease and to detect and treat lesions, other alternative methods for assessing claw disorders should be investigated. Reliable, noninvasive methods are needed to measure the claw 
temperature frequently. One possible method is infrared thermography (IRT) for assessing claw health. Infrared thermography is a noninvasive diagnostic technique that measures emitted radiation and displays the information as a pictorial representation, called a thermogram, of the surface temperature of an object, as infrared radiation (Turner, 1991; Eddy et al., 2001; Kunc et al., 2007). The temperature of extremities and skin is largely dependent on the underlying circulation and tissue metabolism rate (Berry et al., 2003). Therefore, variation in superficial thermal patterns resulting from changes in blood flow (Winsor, 1971) will alter the amount of radiated heat that could be easily identified by IRT and may relate to inflammation of tissues underlying that point or to changes in metabolic activity (Purohit et al., 1985). Increased hoof temperature associated with the onset of lameness suggests a vascular component. For example, Bargai et al. (1992) reported that laminitis is a diffuse aseptic foot inflammation leading to increased hoof temperature.

Infrared thermography was successfully used in various applications of human and veterinary medicine. In farm animals, IRT cameras have been used to test for early detection of estrus (Hurnik et al., 1985), for mastitis (Berry et al., 2003), for detection of viral diarrhea infections in calves (Schaefer et al., 2007), for cattle infected with foot-and-mouth disease (Rainwater-Lovett et al., 2009), and for evaluating the milking process (Kunc et al., 2007).

In equine medicine, IRT has been applied in diagnosing foot and leg problems and as an aid in detection lameness or regions of inflammation in horses (Eddy et al., 2001; Schulze, 2003). More IRT data on the relationship between IRT and hoof disorders to compare its reliability are preferable in preventive claw trimming management. In comparison to other investigations, our research hypothesis focused on radiation of the coronary band (CB). Lameness in dairy cows may be associated with the changes in hoof temperature at the site of the lesion, and radiated heat emitted by the claw in the $\mathrm{CB}$ region could be detected with IRT. Therefore, the objective was to investigate the potential role of using IRT to measure claw temperature as a means to detect lameness in dairy cattle. A secondary aim was to study the effect stage of lactation and ambient temperature on hoof temperature.

\section{MATERIALS AND METHODS}

\section{Animals and Housing}

The experiment was carried out at the research station "Frankenforst" of the University of Bonn. Twentyfour Holstein cows in first $(\mathrm{n}=8)$ and second parity
( $\mathrm{n}=16)$ were selected randomly, either in early to mid-lactation $(\leq 200$ DIM, $\mathrm{n}=16)$ or in late lactation $(>200$ DIM, $n=8)$. Cows were housed in a freestall barn covered by rubber mats and sawdust. The barn contained 62 milking cows. The flooring was grooved concrete. The alley next to the feed bunk $(3.50 \mathrm{~m})$ was covered with a 1.5 -cm-thick rubber mat. Alleys were cleaned 17 times a day with automatic scrapers. The feeding and water troughs were equipped with an individual cow identification system. Cows were fed a TMR ad libitum with fresh feed delivered twice daily at 0900 and $1900 \mathrm{~h}$. The cow to freestall and feeding space ratios were $1: 1$ and $2: 1$, respectively. Cows were fed concentrate from transponder-controlled self-feeders according to their milk yield. The cows were milked twice daily at 0530 and $1630 \mathrm{~h}$ in a double- 4 parallel milking parlor. In 2010, the milk yield of the total herd was $8,687 \pm 1,400$ (mean $\pm \mathrm{SD}$ ) $\mathrm{kg}(305$-d). Cow claws were trimmed routinely 3 times per year according to the Dutch trimming method (Toussaint-Raven, 1985). The cows showed no indications of clinical systemic diseases. Before the research period, the cows had access to pasture; during the study the cows were kept inside the barn.

\section{Experimental Design}

For $3 \mathrm{~d}$ before the claw trimming and lesion examination, IRT images were collected once daily before the afternoon milking. On d 4 of the 7-d collection period, claws of the cows were trimmed by professional hoof trimmers and claw lesions were treated immediately after diagnosis. Following routine claw trimming procedures, thermal images were repeatedly recorded for 3 consecutive days at the same time of the day. In addition, although the cows were habituated to both the facilities and procedures, the hypothalamic-pituitaryadrenal axis may be activated by stress (Stewart et al., 2007), resulting in the release of cortisol as well as blood flow responses, causing thermal temperature increases during handling and claw trimming. To minimize confounding factors, all scans were performed in the milking parlor, eliminating direct sunlight.

Prior to the infrared image measurements, the claws were cleaned with a pressure washer to eliminate the debris from the dorsal surface of the hooves and to avoid temperature variations induced by the presence of debris, which acts as an insulator and reduces the surface temperature (Van Hoogmoed et al., 2000). Following washing, the claws were dried using paper towels. The cows left the milking parlor to the waiting area and returned to the parlor when the infrared images were obtained. This procedure was necessary to ensure that the surface temperature could be measured while con- 
sidering the change of hoof temperature caused by exercise. The barn alley and waiting area were scraped and covered with sawdust to keep the claws dry and clean.

\section{Clinical Examination}

Claw disorders of the hind-legs were recorded during the routine herd-trimming event. The diagnoses of claw disorders were performed based on visual inspection, softness of the horn tissue, and evaluation of smells and pain reactions of the cows as described by Espinasse et al. (1984). This was considered as the gold standard test (reference test) for detection of hoof lesions.

The presence of disorders was recorded as 0 (absent) or 1 (present) if the disorder was diagnosed in at least 1 hind claw. No severity score was documented in this study. Claw lesions identified included digital dermatitis $(\mathrm{n}=6)$, pododermatitis aseptica diffusa (laminitis; $\mathrm{n}=9)$, white-line disease $(\mathrm{n}=1)$, sole ulcer $(\mathrm{n}=2)$, interdigital dermatitis/heel-horn erosion $(\mathrm{n}=1)$, double sole $(\mathrm{n}=1)$, and interdigital hyperplasia $(\mathrm{n}=4)$.

\section{Thermal Imaging}

The thermal images were obtained with a Jenoptik VarioCAM high-resolution, long-wave thermal camera (7.5 to $14 \mu \mathrm{m}$; series model "research"), with 60 individual frames/s recording, and analyzed using Irbis 3 Imager software Jenoptik AG (InfraTec GmbH, Dresden, Germany). The software permitted analysis of temperatures within a specific area using a geometric figure drawn on the desired area. The program allowed the user to display the temperature at any given area on the image and calculated the minimum, maximum, and average temperatures and standard deviation for each measuring field. Additionally, thermograph resolution was calibrated to ambient temperature before each collection session.

The emissivity value $(\varepsilon)$ was set to 0.98 , which refers to the object's ability to absorb and emit infrared radiation. The camera was used in a fixed position and all images were captured at a distance of about $0.5 \mathrm{~m}$ distance from the subject. The images displayed in a focal plane array arrangement had a solution of 1,280 $\times 1,024$ pixels. The planar images were scanned with $0^{\circ}$ angle for the right and left claws (Figure 1). The total surface of the $\mathrm{CB}$ from the hind limbs was scanned, and an area of $4.2 \times 4.2 \mathrm{~mm}^{2}$ was used for the hot-spot detection. The image analysis software Irbis 3 was used to determine (1) the CB region, which is defined as the junction between the skin and the horn of the claw, (2) the skin (S), $2 \mathrm{~cm}$ above the $\mathrm{CB}$, and (3) the temperature difference between $\mathrm{CB}$ and $\mathrm{S}(\boldsymbol{\Delta} \mathbf{T})$, calculated by subtracting the mean temperature value of $\mathrm{S}$ from that of the CB of the each hind limb.

The relevant temperature was defined by tracing the hottest area of $\mathrm{CB}$, excluding the cleft between the lateral and medial claws, using tools within the image analysis software. The medial and lateral claws were analyzed together for each hind limb.
A

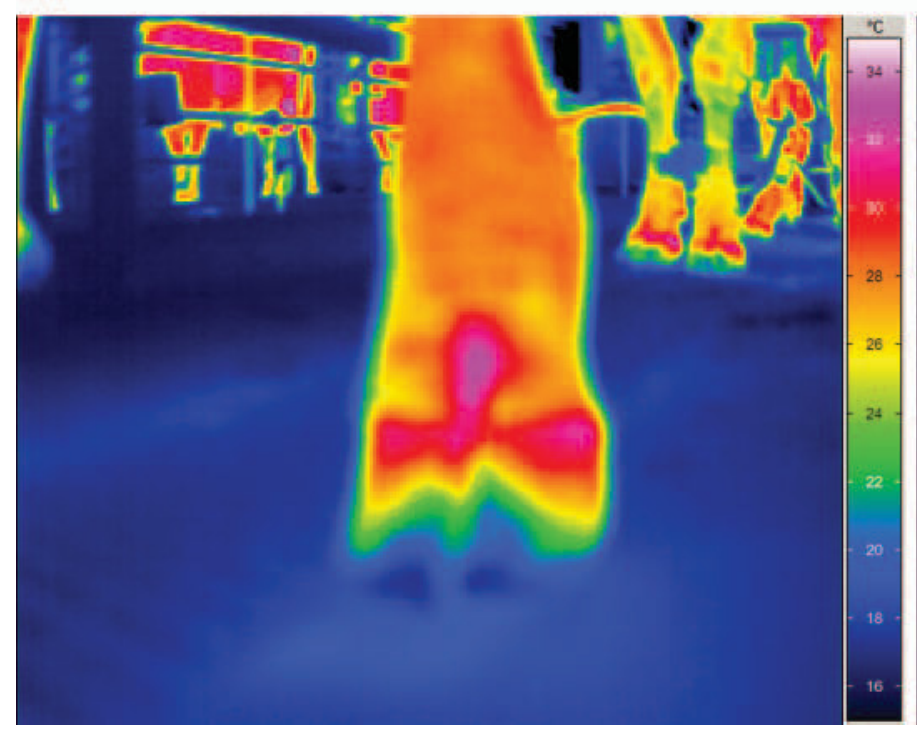

B

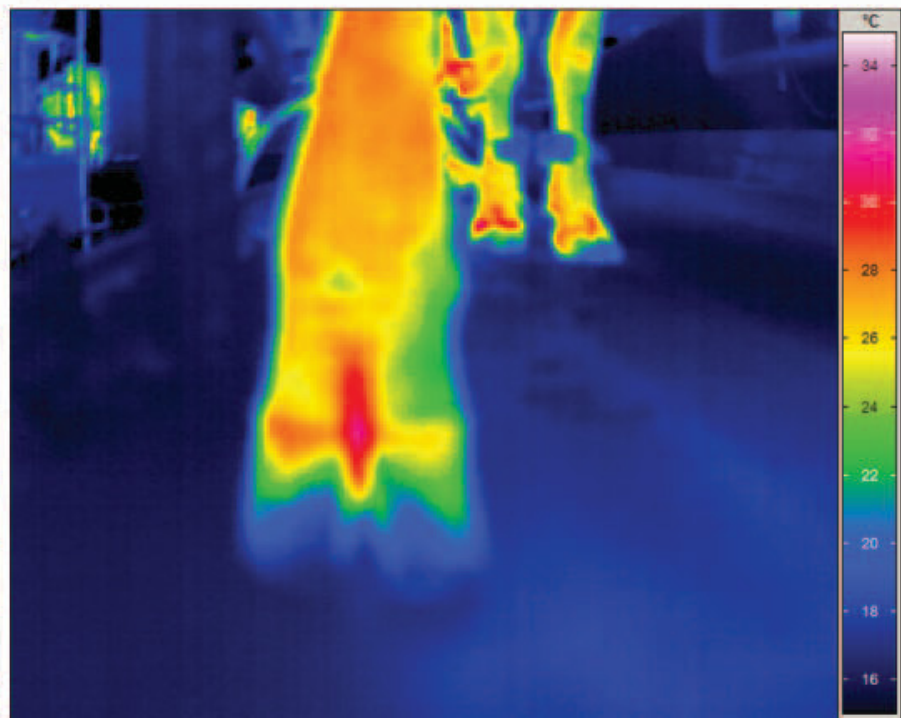

Figure 1. Infrared images of plantar $(\mathrm{A})$ left $(1=$ lesion $)$ and $(\mathrm{B})$ right $(0=$ sound $)$ hind hoof (stall no. 36) obtained before claw trimming. The red and blue colors of the scale represent the warmest and coolest areas, respectively. The thermal images show temperature differences $\left({ }^{\circ} \mathrm{C}\right)$ on coronary band between lesion (A) and nonlesion (B) hind claws. 
In addition, the span of camera and temperature range of the color scale was adjusted so that the $\mathrm{CB}$ would usually appear white or red, whereas the coolest region of the image appeared black or blue, thus maximizing the visual comparison of the thermal image. The images were recorded as infrared image files and stored on a compact flash memory card within the camera. The data files were subsequently transferred to the computer for image analysis using Irbis 3 Imager software.

A data logger was used to measure the ambient temperature over the 6 - $d$ collection period inside the parlor. Measurements of ambient temperature were taken at the same time as the thermal imaging.

\section{Statistical Analysis}

In total, 626 individual recordings were collected from 24 cows before and after claw trimming. Only 12 cows had at least 1 lesion on the left or right hind claw. To identify the best site for claw abnormality screening, average, maximum, and minimum foot temperatures were plotted against clinical incidence. Furthermore, a receiver operating characteristic analysis (ROC; Figures 2 and 3 ) was used to compare the diagnostic performance of nonlesions (0) and lesions (1) and calculate the optimal efficiency threshold values by estimating differences of the area under the ROC curves and by using the statistical package software MedCalc (Version 11.6, 2011; MedCalc Software, http://www.medcalc. org).

The accuracy analyses (sensitivity, specificity, positive predictive value, and negative predictive value) were conducted assuming that the diagnosis of lesion during hoof trimming was the reference test for detection of hoof lesions.

Before comparing temperature differences between lesion and nonlesion limbs, the data were reported as individual temperature difference. This was done by subtracting the average, minimum, and maximum values of the $\mathrm{CB}$ and $\mathrm{S}$ temperatures, as well as $\Delta \mathrm{T}$ between the same anatomical regions of the left and right claw. This was important in avoiding the variability in IRT data between the cows and at different ambient temperatures. Because of the small number of data samples tested each day $(\mathrm{n}=24)$, the data were analyzed separately to form a single data set as pre- and post-trimming data. The claw disorders were used as main factors in the model. Pearson correlations were used at the cow level to determine the effect of ambient temperature on claw surface temperature. The conjunctions between the change of temperatures for healthy hooves and stage of lactation were evaluated using Wilcoxon rank-sum analysis as a nonparametric statistical procedure. The levels of significance were $P$ $<0.01$ and $P<0.05$.

\section{RESULTS}

\section{Thermography and Ambient Temperature}

The ambient temperature in the parlor ranged between $12.2^{\circ} \mathrm{C}$ and $20.3^{\circ} \mathrm{C}$, with a mean of $14.1 \pm 3.2^{\circ} \mathrm{C}$ (mean $\pm \mathrm{SD}$ ). A positive correlation was demonstrated between parlor temperature and foot temperature in the $\mathrm{CB}$ and $\mathrm{S}$ regions $\left(\mathrm{R}^{2}=0.92\right.$ and $\mathrm{R}^{2}=0.99$, respectively; $P<0.01 ;$ Figure 4$)$. This indicated that foot temperatures detected by IRT were affected by ambient temperatures.

The overall means ( \pm SEM) of $\mathrm{CB}$ and $\mathrm{S}$ temperatures, respectively, in healthy claws were $30.3 \pm 3.2^{\circ} \mathrm{C}$ and $27.3 \pm 2.9^{\circ} \mathrm{C} ; 32.1 \pm 1.7^{\circ} \mathrm{C}$ and $28.6 \pm 2.1^{\circ} \mathrm{C}$; and $33.8 \pm 1.3^{\circ} \mathrm{C}$ and $29.9 \pm 1.8^{\circ} \mathrm{C}$ for ambient temperatures of $12.2,15.7$, and $20.3^{\circ} \mathrm{C}$, respectively.

\section{Effects of Stage of Lactation}

The $\mathrm{CB}, \Delta \mathrm{T}(P<0.01)$, and $\mathrm{S}$ temperatures $(P<$ $0.05)$ were higher in cows $\leq 200$ DIM than in cows $>200$

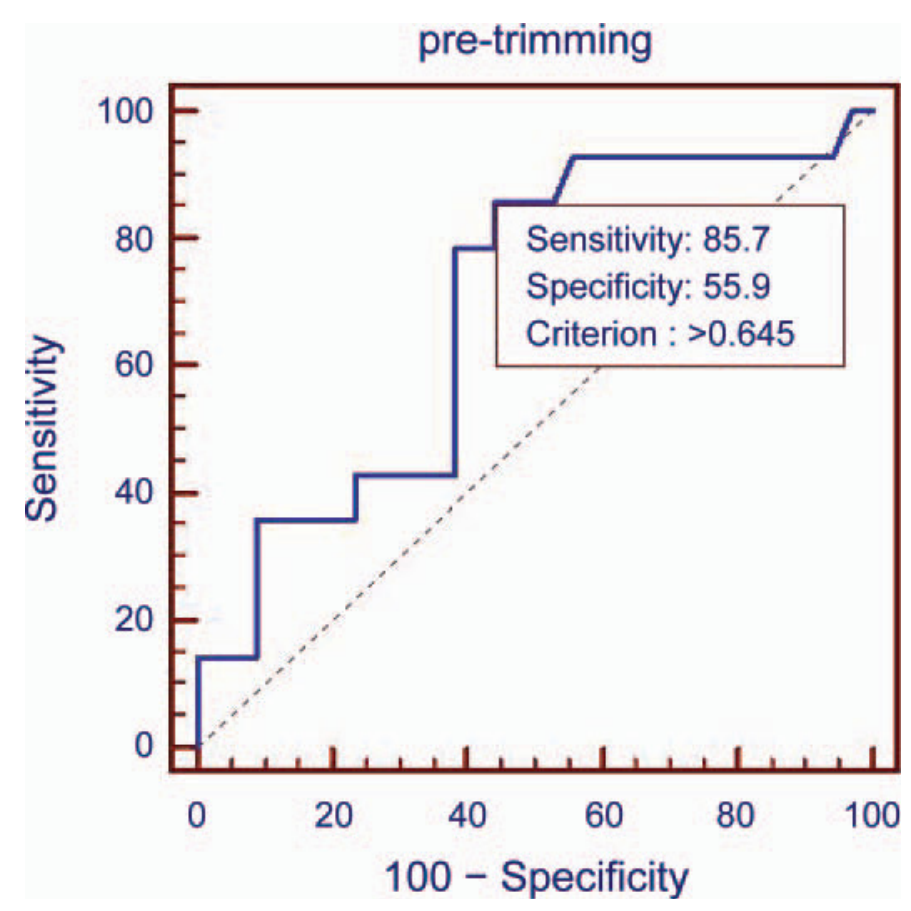

Figure 2. Response operant characteristic curve for coronary band hind claws infrared generated for pre-trimming event. The true positive rate (sensitivity) is plotted as a function of the false positive rate (100 - specificity) for different thresholds. The area under the receiver operating characteristics curve for infrared thermography was 0.689 $(\mathrm{z}$-value $=2.218, P=0.026)$. Color version available in the online PDF. 


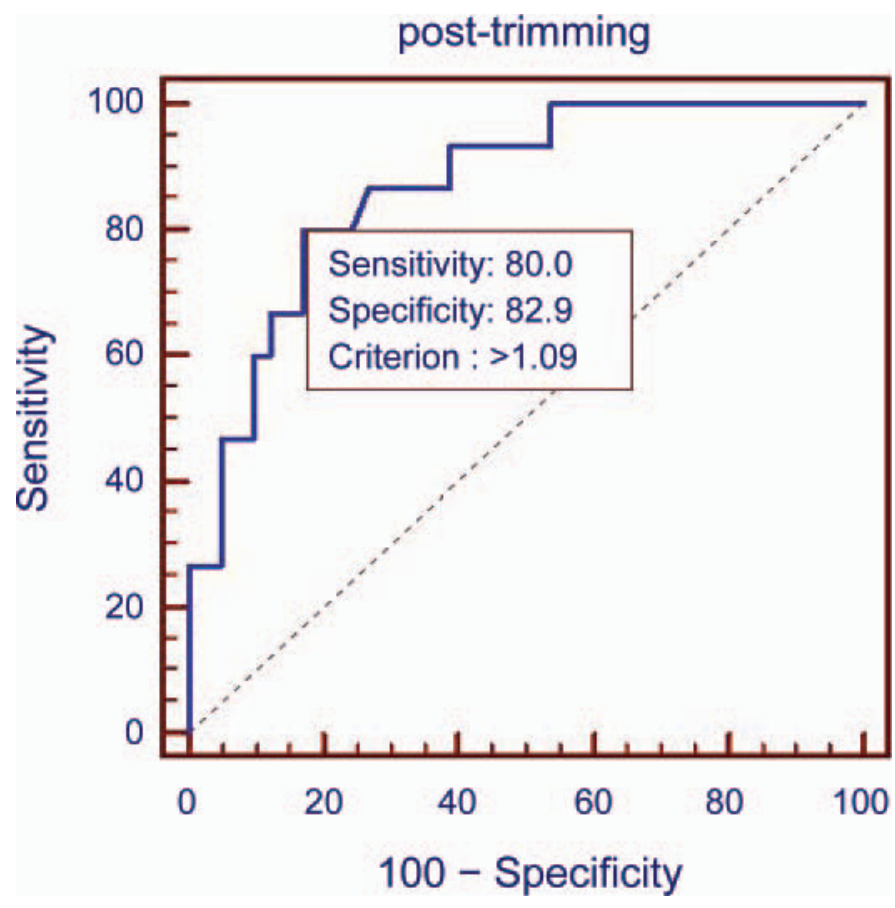

Figure 3. Response operant characteristic curve for coronary band hind claws infrared generated for post-trimming event. The area under the receiver operating characteristics curve for infrared thermography was 0.689 (z-value $=7.228, P<0.0001)$. The $\mathrm{x}$-axis defines the value 100 - specificity, whereas the y-axis defines the sensitivity in a range from 0 to $100 \%$. Color version available in the online PDF.
DIM for all healthy hooves, indicating a higher temperature of all hoof regions of cows in early/mid lactation compared with cows in late lactation. In general, hoof $\mathrm{CB}$ temperature, $\mathrm{S}$ temperature, and $\Delta \mathrm{T}$ were $31.8 \pm$ 2.7 vs. $29.8 \pm 3.6 ; 28.5 \pm 2.5$ vs. $27.2 \pm 3.3$; and 3.3 \pm 1.7 vs. $2.5 \pm 1.3$ for early/mid versus late lactation.

\section{Pre- and Post-Trimming IRT Data Analysis}

The infrared thermal data were used to develop a predictive index by establishing threshold values for the $\mathrm{CB}$ temperatures in pre- and post-trimming data sets. In the pre-trimming data analysis, a difference was found in $\mathrm{CB}$ temperature between cows with lesions and cows without lesions $(P<0.05)$. A trend was observed for cows with lesions to have a higher temperature in the $\mathrm{S}$ region $(P=0.057)$; however, $\Delta \mathrm{T}$ did not differ $(P=0.38)$ over the $3 \mathrm{~d}$ before trimming. In the post-trimming analysis, differences in temperature of the $\mathrm{CB}, \mathrm{S}$, and $\Delta \mathrm{T}$ between lesion and nonlesion cows over the $3 \mathrm{~d}$ post-trimming were detectable (Table $1 ; P<0.01)$.

\section{Sensitivity and Specificity}

Pre-trimming and post-trimming $\mathrm{CB}$ temperature differences from all lesion and nonlesion hind claws

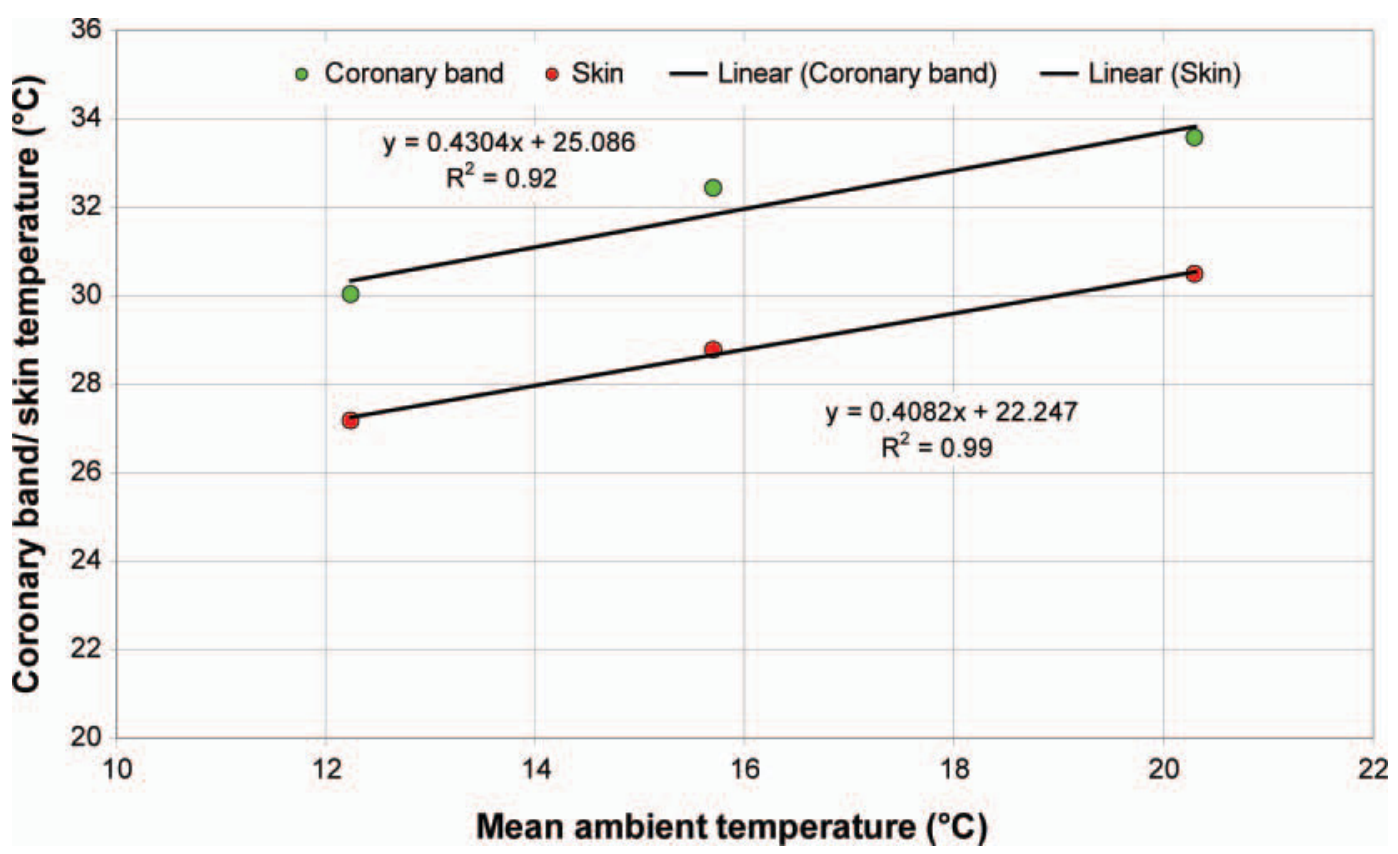

Figure 4. Correlation coefficients between ambient and hoof thermal measurements in healthy hooves. Coronary band and skin regions were positively correlated $(P<0.01)$ with thermal images of parlor temperatures, regardless of stage of lactation. Color version available in the online PDF. 
Table 1. The overall means $( \pm \mathrm{SD})$ of the temperature differences for coronary band temperature $(\mathrm{CB})$, skin temperature $(\mathrm{S})$, and the temperature difference $(\Delta \mathrm{T})$ between left and right limb measured by infrared thermography of nonlesion and lesion hind claws pre- and posttrimming

\begin{tabular}{|c|c|c|c|c|c|c|c|c|}
\hline \multirow[b]{2}{*}{ Item } & \multicolumn{4}{|c|}{ Pre-trimming } & \multicolumn{4}{|c|}{ Post-trimming } \\
\hline & Mean & $\mathrm{SD}$ & Mean & $\mathrm{SD}$ & Mean & $\mathrm{SD}$ & Mean & $\mathrm{SD}$ \\
\hline $\mathrm{CB},{ }^{\circ} \mathrm{C}$ & 0.68 & 0.57 & 1.32 & 0.92 & 0.77 & 0.76 & 2.40 & 1.59 \\
\hline $\mathrm{S},{ }^{\circ} \mathrm{C}$ & 1.45 & 1.01 & 0.88 & 0.63 & 0.87 & 0.73 & 2.15 & 1.86 \\
\hline$\Delta \mathrm{T},{ }^{\circ} \mathrm{C}$ & 1.24 & 0.89 & 1.64 & 0.95 & 0.71 & 0.60 & 2.18 & 1.37 \\
\hline
\end{tabular}

were used to calculate a threshold value by utilizing ROC curves, and efficiency calculations were completed in the true positive and true negative population. The threshold values established were 0.64 for pre-trimming event (sensitivity $=85.7 \%$, specificity $=55.9 \%$; Figure 2, Table 2) and 1.09 for post-trimming event (sensitivity $=80.82 \%$, specificity $=82.9 \%$; Figure 3 , Table 3 ).

\section{DISCUSSION}

Although IRT has been available to assist in the diagnosis of inflammatory conditions in veterinary medicine for several years, little information is available regarding the use of IRT associated with lameness detection in dairy cows.

In the studies of Wilhelm (2010) and Schmidt et al. (2003), the images were taken on the sole of each claw, whereas in the current study, the thermal images were taken on the $\mathrm{CB}$. We focused on the $\mathrm{CB}$ region because unlike the sole, it has a highly vascularized area supplying blood throughout the corium. An advantage of this method is that it does not require direct physical contact with the hoof, thus allowing for remote reading of the temperature without disturbance of animal behavior. The IRT may only be useful to measure the surface temperature of the $\mathrm{S}$ region. The $\mathrm{CB}$ was the hottest area within the thermograms taken from the dorsal view of the limb, reflecting its high vascularity. Turner (2001) reported that the CB is the warmest area above the hoof in horses and the $\mathrm{CB}$ is 1 to $2^{\circ} \mathrm{C}$ warmer than the $\mathrm{S}$. Here, the $\mathrm{CB}$ was 2 to $3^{\circ} \mathrm{C}$ warmer than the $\mathrm{S}$. Environmental conditions such as ambient temperature affect the reliability of thermal images. For such investigations, the cows should be in their thermal neutral zone. With increasing ambient temperature, the claw temperature increases from 12 to $20^{\circ} \mathrm{C}$. Love and Linsted (1976) have reported that the ideal ambient temperature for imaging is in the range of $20^{\circ} \mathrm{C}$. The ambient temperature in the current study did not exceed $20.3^{\circ} \mathrm{C}$, which is acceptable.

Furthermore, claw temperature values varied at different stages of lactation suggesting a higher temperature of all hoof regions compared with cows in late lactation. This supports Nikkhah et al. (2005), who reported that $\mathrm{CB}$ temperature and $\Delta \mathrm{T}$ were higher in early or mid lactation cows compared with late lactation cows.

Whay et al. (2004) found differences in surface temperatures on the side of a lame limb by examining the hind limb in dairy cows. Concurrently, these results indicate that each cow can serve as her own control

Table 2. The sensitivity and specificity of the temperature differences for coronary band temperature (CB), skin temperature (S), and the temperature difference $(\Delta \mathrm{T})$ between $\mathrm{CB}$ and $\mathrm{S}$ determined by infrared thermography for lesion detection in hind claws pre-trimming

\begin{tabular}{|c|c|c|c|c|c|c|c|c|}
\hline Item & $\begin{array}{l}\text { Threshold } \\
\text { value },{ }^{\circ} \mathrm{C}\end{array}$ & $\begin{array}{c}\text { Sensitivity }^{2} \\
(95 \% \text { CI })\end{array}$ & $\begin{array}{c}\text { Specificity }^{3} \\
(95 \% \text { CI })\end{array}$ & \multicolumn{2}{|c|}{ Likelihood ratio (95\% CI) } & \multicolumn{2}{|c|}{ Predictive value $(95 \%$ CI $)$} & $P$-value ${ }^{4}$ \\
\hline $\mathrm{CB},{ }^{\circ} \mathrm{C}$ & $>0.64$ & $\begin{array}{l}85.7 \\
(57.2-98.2)\end{array}$ & $\begin{array}{l}55.9 \\
(37.9-72.8)\end{array}$ & $\begin{array}{l}1.94 \\
(1.3-2.8)\end{array}$ & $\begin{array}{l}0.26 \\
(0.07-1.0)\end{array}$ & $\begin{array}{l}44.4 \\
(25.5-64.7)\end{array}$ & $\begin{array}{l}90.5 \\
(69.6-98.8)\end{array}$ & 0.026 \\
\hline $\mathrm{S},{ }^{\circ} \mathrm{C}$ & $\leq 1.90$ & $\begin{array}{l}100.0 \\
(76.8-100.0)\end{array}$ & $\begin{array}{l}29.4 \\
(15.1-47.5)\end{array}$ & $\begin{array}{l}1.42 \\
(0.8-2.4)\end{array}$ & ND & $\begin{array}{l}36.8 \\
(21.8-54.0)\end{array}$ & $\begin{array}{l}100.0 \\
(69.2-100.0)\end{array}$ & 0.057 \\
\hline$\Delta \mathrm{T},{ }^{\circ} \mathrm{C}$ & $>0.63$ & $\begin{array}{l}85.7 \\
(57.2-98.2)\end{array}$ & $\begin{array}{l}35.3 \\
(19.7-53.5)\end{array}$ & $\begin{array}{l}1.32 \\
(0.8-2.2)\end{array}$ & $\begin{array}{l}0.40 \\
(0.1-1.5)\end{array}$ & $\begin{array}{l}35.3 \\
(19.7-53.5)\end{array}$ & $\begin{array}{l}85.7 \\
(57.2-98.2)\end{array}$ & 0.38 \\
\hline
\end{tabular}

\footnotetext{
${ }^{1}$ Threshold value for temperature differences in ${ }^{\circ} \mathrm{C}$ between lesion (1) and nonlesion (0) hind claws determined by the response operant characteristic (ROC) analysis.

${ }^{2}$ Sensitivity: probability that a test result will be positive when the lesion is present $(1=$ lesion $)$.

${ }^{3}$ Specificity: probability that a test result will be negative when the lesion is not present $(0=$ nonlesion).

${ }^{4} P$-value for the area under the receiver operating characteristic analysis (ROC) curve for infrared thermography (IRT) and hoof lesion detection; differences are significant when the area under the ROC curve is greater than 0.5 .
} 
Table 3. The sensitivity and specificity of the temperature differences for coronary band temperature (CB), skin temperature (S), and the temperature difference $(\Delta \mathrm{T})$ between $\mathrm{CB}$ and $\mathrm{S}$ determined by infrared thermography for lesion detection in hind claws post-trimming

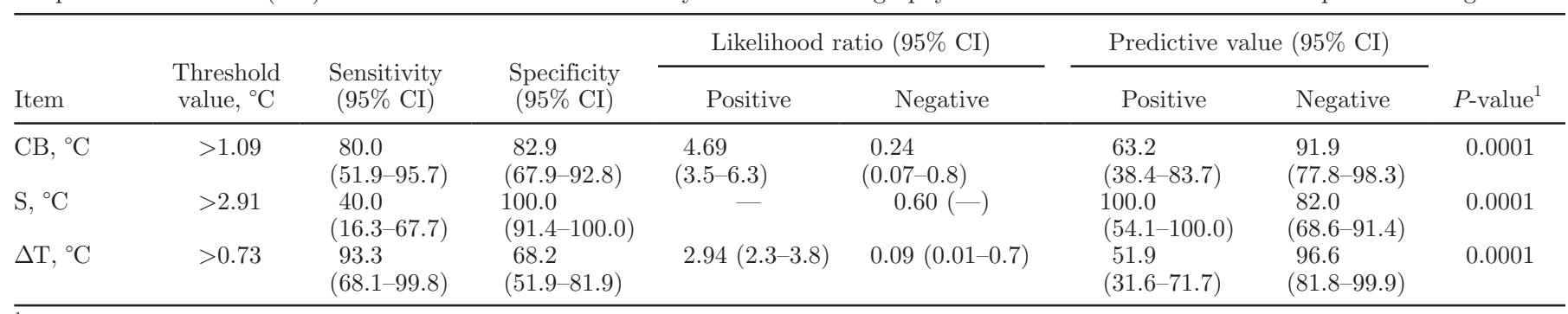

${ }^{1} P$-value for the area under the receiver operating characteristic analysis (ROC) curve for infrared thermography (IRT) and hoof lesion detection; differences are significant when the area under the ROC curve is greater than 0.5 .

for surface temperature variations. Therefore, in the pre- and post-trimming analysis of cows with a lesion in only 1 hind limb (0 vs. 1$)$, differences were expected in CB temperature between lesion and nonlesion limbs. For this purpose, a ROC curve analysis was performed, and the optimal relationship between true positive rate (sensitivity) and false positive rate (100 - specificity) was determined when a threshold value of CB temperature difference of 0.64 and $1.09^{\circ} \mathrm{C}$ was used to detect hoof lesion in pre- and post-trimming data analysis, respectively.

The differences between the pre- and post-trimming measurements were difficult to explain thermographically. van der Tol et al. (2004) reported that cows put more weight on the hind limbs after preventive trimming, which causes an increase in force and pressure. Further studies should investigate the effects of preventive hoof trimming based on surface temperature values. These temperature changes may have been associated with the type and severity of the hoof lesions. The severity and location of the foot lesions were not quantified in this study. Consequently, the results demonstrate an increase in temperature of the lame limb, when lesions occurred at least in both the left and right hind limbs. To integrate thermographic data with other standard methods of lameness evaluation would improve the utilization and understanding of the diagnostic potential of thermography technology. Further work is necessary to combine thermography with other electronic methods of lameness detection and to elucidate their association with lesion-specific lameness.

\section{CONCLUSIONS}

Thermographic imaging shows promise as a diagnostic tool for detection of hoof lesions in dairy cows. The ability to detect potential of pathology and associated inflammation from changes in the $\mathrm{CB}$ in a noninvasive manner is very desirable. Evidence supports the hypothesis that CB temperature, measured by IRT, increases the detection of abnormalities of the hoof before routine hoof trimming. A combination of thermography image analysis with clinical examination would be a helpful technique for preventing lameness. Therefore, IRT may be used in the future to help veterinarians and herd managers detect hoof lesions associated with lameness in dairy cows. The comparison of the presented method with other systems of hoof lesion detection is needed.

\section{ACKNOWLEDGMENTS}

This research was supported by the Syrian Government Scholarship of the High Education Ministry (AlBaath University, Homs, Syria). The authors thank the farm manager and all farm staff of the Research Centre Frankenforst (Bonn University, Germany) for supporting the experiments. We thank Helga Sauerwein and the Department of Physiology and Hygiene at the Institute for Animal Science (University of Bonn) and Christoph Römer (Institute of Geodesy and Geoinformation, University of Bonn) for their support.

\section{REFERENCES}

Alsaaod, M., and W. Büscher. 2009. Early lameness detection in dairy cows with electronic activity sensors. Landtechnik 64:413-416.

Bargai, U., I. Shamir, A. Lublin, and E. Bogin. 1992. Winter outbreaks of laminitis in dairy calves: Aetiology and laboratory, radiological and pathological findings. Vet. Rec. 131:411-414.

Berry, R. J., A. D. Kennedy, S. L. Scott, B. L. Kyle, and A. L. Schaefer. 2003. Daily variation in the udder surface temperature of dairy cows measured by infrared thermography: Potential for mastitis detection. Can. J. Anim. Sci. 83:687-693.

Eddy, A. L., L. M. van Hoogmoed, and J. R. Snyder. 2001. Review: The role of thermography in the management of equine lameness. Vet. J. 162:172-181.

Espinasse, J., M. Savey, C. M. Thorley, E. Toussaint Raven, and A. D. Weaver. 1984. Colour Atlas on Disorders of Cattle and Sheep Digit. International Terminology. Societé Francaise de Buiatrie, Maisons-Alfort Cedex, France.

Flower, F. C., and D. M. Weary. 2006. Effect of hoof pathologies on subjective assessments of dairy cow gait. J. Dairy Sci. 89:139-146.

Green, L. E., V. J. Hedges, Y. H. Schukken, R. W. Blowey, and A. J. Packington. 2002. The impact of clinical lameness on the milk yield of dairy cows. J. Dairy Sci. 85:2250-2256. 
Hurnik, J. F., A. B. Webster, and S. DeBoer. 1985. An investigation of skin temperature differentials in relation to estrus in dairy cattle using a thermal infrared scanning technique. J. Anim. Sci. 61:1095-1102.

Kunc, R., I. Knížková, M. Přikryl, and J. Maloun. 2007. Infrared thermography as a tool to study the milking process: A review. Agric. Trop. Subtrop. 40:29-32.

Liu, J., R. M. Dyer, N. K. Neerchal, U. Tasch, and P. G. Rajkondawar. 2011. Diversity in the magnitude of hind limb unloading occurs with similar forms of lameness in dairy cows. J. Dairy Res. $78: 168-177$.

Love, T. J., and R. D. Linsted. 1976. Theoretical basis for use of skin temperature as a plethysmographic indicator. Paper 75-WA/Bio6:1-4 in Proc. Am. Soc. Mech. Eng. Winter Annual Mtg.

Murray, R. D., D. Y. Downham, M. J. Clarkson, W. B. Faull, J. W. Hughes, F. J. Manson, J. B. Merritt, W. B. Russell, J. E. Sutherst, and W. R. Ward. 1996. Epidemiology of lameness in dairy cattle: Description and analysis of foot lesions. Vet. Rec. 138:586-591.

Nikkhah, A., J. C. Plaizier, M. S. Einarson, R. J. Berry, S. L. Scott, and A. D. Kennedy. 2005. Infrared thermography and visual examination of hooves of dairy cows in two stages of lactation. J. Dairy Sci. 88:2749-2753.

Pastell, M., H. Tamkko, H. Gröhn, M. Hautala, V. Poikalainen, J. Praks, I. Veermäe, M. Kujala, and J. Ahokas. 2006. Assessing cows' welfare: Weighing the cow in a milking robot. Biosystems Eng. 93:81-87.

Purohit, R. C., R. S. Hudson, M. G. Riddell, R. L. Carson, D. F. Wolfe, and D. F. Walker. 1985. Thermography of the bovine scrotum. Am. J. Vet. Res. 46:2388-2392.

Rainwater-Lovett, K., J. M. Pacheco, C. Packer, and L. L. Rodriguez. 2009. Detection of foot-and-mouth disease virus infected cattle using infrared thermography. Vet. J. 180:317-324.

Rutherford, K. M. D., F. M. Langford, M. C. Jack, L. Sherwood, A. B. Lawrence, and M. J. Haskell. 2009. Lameness prevalence and risk factors in organic and non-organic dairy herds in the United Kingdom. Vet. J. 180:95-105.

Schaefer, A. L., N. J. Cook, J. S. Church, J. Basarab, B. Perry, C. Miller, and A. K. W. Tong. 2007. The use of infrared thermography as an early indicator of bovine respiratory disease complex in calves. Res. Vet. Sci. 83:376-384.

Schmidt, S. J., S. D. Bowers, K. B. Graves, R. Carroll, J. White, and S. T. Willard. 2003. Use of digital infrared thermography to assess thermal temperature gradients and pathologies of the bovine claw. J. Dairy Sci. 86(Suppl. 1):322. (Abstr.)
Schulze, M. 2003. Thermographie am Huf. Vet. med. Diss. Univ. Berlin, Germany.

Stewart, M., J. R. Webster, G. A. Verkerk, A. L. Schaefer, J. J. Colyn, and K. J. Stafford. 2007. Non-invasive measurement of stress in dairy cows using infrared thermography. Physiol. Behav. 92:520525 .

Tadich, N., E. Flor, and L. Green. 2010. Associations between hoof lesions and locomotion score in 1098 unsound dairy cows. Vet. J. 184:60-65.

Toussaint-Raven, E. 1985. Symp. Bovine Lameness and Orthopedics: The principles of claw trimming. Vet. Clin. North Am. Food Anim. Pract. 1:93-107.

Turner, T. A. 1991. Thermography as an aid to the clinical lameness evaluation. Vet. Clin. North Am. Equine Pract. 7:311-338.

Turner, T. A. 2001. Diagnostic thermography. Vet. Clin. North Am. Equine Pract. 17:95-113.

van der Tol, P. P., S. S. van der Beek, J. H. Metz, E. N. NoordhuizenStassen, W. Back, C. R. Braam, and W. A. Weijs. 2004. The effect of preventive trimming on weight bearing and force balance on the claws of dairy cattle. J. Dairy Sci. 87:1732-1738.

Van Hoogmoed, L., J. R. Snyder, A. K. Allen, and J. D. Waldsmith. 2000. Use of infrared thermography to detect performance-enhancing techniques in horses. Equine Vet. Educ. 12:102-107.

Whay, H. R., M. J. Bell, and D. C. J. Main. 2004. Validation of lame limb identification through thermal imaging. Pages 237-238 in Proc. 13th Int. Conf. Lameness in Ruminants, Maribor, Slovenia. University of Bristol, Langford, Bristol, UK.

Whay, H. R., D. C. Main, L. E. Green, and A. J. Webster. 2003. Assessment of the welfare of dairy cattle using animal-based measurements: Direct observations and investigation of farm records. Vet. Rec. 153:197-202.

Whay, H. R., A. E. Waterman, A. J. F. Webster, and J. K. O'Brien. 1998. The influence of lesion type on the duration of hyperalgesia associated with hindlimb lameness in dairy cattle. Vet. J. 156:23-29.

Wilhelm, K. 2010. Die subklinische Klauenrehe beim MilchrindThermographische Untersuchungen der Klaue und Beziehungen zum Energiestoffwechsel. Vet. med. Diss. University of Leipzig, Germany.

Winckler, C., and S. Willen. 2001. The reliability and repeatability of a lameness scoring system for use as an indicator of welfare in dairy cattle. Acta Agric. Scand. Anim. Sci. Suppl. 30:103-107.

Winsor, T. 1971. Vascular aspects of thermography. J. Cardiovasc. Surg. (Torino) 12:379-388. 